\title{
Effect of Tumor Microenvironment on Selective Uptake of Boric Acid in HepG2 Human Hepatoma Cells
}

\author{
YU-CHI BAI ${ }^{1,2}$, YU-CHUN HSIA ${ }^{1,2}$, YU-TING LIN $^{3}$, KUAN-HAO CHEN $^{1,2}$, \\ FONG- IN CHOU ${ }^{3}$, CHIA-MIN YANG ${ }^{4}$ and YUNG-JEN CHUANG ${ }^{1,2}$ \\ ${ }^{1}$ Department of Medical Science, ${ }^{2}$ Institute of Bioinformatics and Structural Biology, \\ ${ }^{3}$ Nuclear Science and Technology Development Center, and \\ ${ }^{4}$ Department of Chemistry, National Tsing Hua University, Hsinchu, Taiwan, R.O.C.
}

\begin{abstract}
Background: Feasibility and efficacy of boric acid (BA)-mediated boron neutron capture therapy (BNCT) was first demonstrated by eliminating hepatocellular carcinoma (HCC) in a rat model. Furthermore, selective uptake of BA by liver tumor cells was shown in a rabbit model. To gain further insight, this study aimed to investigate the mechanisms of transportation and selective uptake of BA in HepG2 liver tumor cells. Materials and Methods: Transportation of BA in HepG2 cells was analyzed by time-course assays and by analyzing the rate of diffusion versus the concentration of $B A$. The effect of different tumor conditions on BA uptake was studied by treating HepG2 cells with $25 \mu \mathrm{g}{ }^{10} \mathrm{~B} / \mathrm{ml} \mathrm{BA}$ under different concentrations of glucose, at different $p H$ and in the presence of water-soluble cholesterol. Results: HepG2 cells mainly uptake BA by simple diffusion. Cell membrane permeability may also contribute to tumor-specific uptake of $B A$. Conclusion: The selective uptake of BA was achieved primarily by diffusion, while other factors, such as low $\mathrm{pH}$ and increased membrane fluidity, which are hallmarks of HCC, might further enhance BA uptake.
\end{abstract}

Hepatocellular carcinoma (HCC) is one of the most common types of cancer worldwide (1). While new treatments are continually evolving, HCC remains a significant cause of death, especially in people with cirrhosis.

Current clinical guidelines suggest treating HCC with

Correspondence to: Professor Yung-Jen Chuang, Ph.D., Department of Medical Science \& Institute of Bioinformatics and Structural Biology, National Tsing Hua University, No.101, Section 2, KuangFu Road, Hsinchu, Taiwan, 30013, R.O.C. Tel: +886 35742764, Fax: +886 35715934, e-mail:yjchuang@life.nthu.edu.tw

Key Words: Hepatocellular carcinoma (HCC), boron neutron capture therapy (BNCT), boric acid, transportation, cell membrane permeability, acidic microenvironment. resection, transplantation, radiofrequency ablation, transcatheter arterial embolization, or administration of the kinase inhibitor sorafenib $(2,3)$. With these treatment options, the 5-year survival rates of patients who underwent liver resection and transplantation for early-stage HCC are $50-70 \%$ and $70-80 \%$, respectively (4). However, more than $80 \%$ of patients with HCC are diagnosed with intermediateor advanced-stage disease and are not surgical candidates due to either multifocal disease occurrences or vascular invasion (5). Such patients will receive palliative care and have a poor 5-year survival rate.

For treating advanced $\mathrm{HCC}$, the multikinase inhibitor sorafenib (also known as Nexavar) is the only United States Food and Drug Administration-approved drug available today. While sorafenib has been shown to improve survival rate in patients with unresectable disease by approximately 3 months (6), it has various adverse effects, including poor liver function and diarrhea. Additionally, some patients with HCC do not respond to the treatment (7). As a result, the clinical challenge for advanced HCC is to find an effective treatment with tolerable side-effects.

Boron neutron capture therapy (BNCT) could be a promising treatment option for HCC. BNCT already has proven its efficacy in various human cancer types, including head and neck cancer, melanoma, and malignant glioma (810). In terms of its mechanism of action, BNCT makes use of thermal or epithermal neutrons to irradiate tumors that have been previously loaded with boron drug containing the stable ${ }^{10} \mathrm{~B}$ isotope. The resulting reaction generates ${ }^{4} \mathrm{He}$ and ${ }^{7} \mathrm{Li}$ particles within the tumor cells. Because of the short reaction range and high linear energy transfer, nearly all the energy is released inside the tumor. As a result, the tumor cells are eliminated, while the neighboring normal cells remain unharmed.

One challenging aspect of BNCT is to find a boron drug that can be selectively absorbed by the tumor cells. The available boron drugs for BNCT are borocaptate sodium 
(BSH) and boronophenylalanine (BPA). However, these are not suitable for HCC treatment because of the low tumor-tonormal $(\mathrm{T} / \mathrm{N})$ uptake of $\mathrm{BSH}$ in liver tumors and the high accumulation of BPA in the pancreas (11-13).

In recent years, the therapeutic efficacy of boric acid [BA; $\left.\mathrm{B}(\mathrm{OH})_{3}\right]$ as the boron drug for BNCT has been re-examined. BA-mediated BNCT has been demonstrated to have promising efficacy and safety in xenograft models of hepatoma in rats and rabbits in studies performed by Chou et al. $(14,15)$. In these preclinical studies, the research team demonstrated that the selective accumulation of BA in liver tumor cells and tumor blood vessels could lead to rapid reduction in tumor size and destruction of the tumor vasculature after neutron irradiation. However, the mechanism of selective uptake and accumulation of BA in liver tumors remains unclear.

Previous studies have indicated that BA is not metabolized in animals and is mainly transported by simple diffusion (16, 17). Such findings also imply that the observed preferential accumulation of BA in tumor tissues might be because of the differences between normal and tumor tissues, including differential carbohydrate uptake, energy metabolism, cellular membrane lipid composition, and $\mathrm{pH}$ value of the microenvironment $(18,19)$.

On the other hand, cancer cells are known for their high glucose uptake, in which glucose transporter activity can be 10- to 12-fold higher than that in normal cells (20). BA can form complexes with cis-diols containing carbohydrates, such as glucose, mannose and galactose, and BAcarbohydrate interactions are reversible in aqueous solution (21). Therefore, it is possible that the selective accumulation of BA in tumors might result from BA-carbohydrate interactions, during which sugars might help prevent BA from diffusing out of cancer cells.

Meanwhile, lipid composition was shown to impact BA diffusion and transportation in an artificial membrane by changing the permeability coefficient of BA (22). Interestingly, the lipid composition of the plasma membrane in cancer cells is different from that in normal cells (23). For instance, triglyceride and cholesterol levels are decreased in hepatoma, especially in advanced hepatomas, which might relate to increased plasma membrane fluidity (24). Thus, it is possible that enhanced cell permeability is due to the differential lipid composition of hepatoma cells compared to normal liver cells, and this might play an important role in the selective uptake of BA by tumor cells.

Last but not the least, the immediate tumor microenvironment has been shown to be more acidic than the surrounding region. The $\mathrm{pH}$ values in tumor blood vessels and the tumor microenvironment have been found to be between 5.0-6.0 and 6.5-6.8, respectively (25). An acidic microenvironment could affect several membrane channels, including sodium channels and calcium channels (18).
Moreover, an acidic microenvironment might contribute to higher cell membrane fluidity, which is positively correlated with cell membrane permeability (26). Consequently, it is possible that an acidic tumor microenvironment might contribute to the selective accumulation of BA inside tumor cells.

In this study, we aimed to clarify the mechanism of BA uptake in hepatoma cells reported in previous in vivo studies $(14,15)$. We investigated whether glucose concentration, $\mathrm{pH}$ value, or cell membrane lipid composition could regulate the selective uptake of BA in HepG2 hepatoma cells. Our findings are critical for planning future BA-BNCT clinical trials for advanced HCC.

\section{Materials and Methods}

Cell culture. HepG2 human hepatocellular carcinoma cells $\left(\mathrm{ATCC}^{\circledR}\right.$ HB-8065; Manassas, VA, USA) were cultured in high glucose (4.5 g/l) Dulbecco's modified Eagle's medium (DMEM; Gibco, El Paso, TX, USA) containing $10 \%$ heat-inactivated fetal bovine serum, $100 \mathrm{unit} / \mathrm{ml}$ streptomycin, $100 \mu \mathrm{g} / \mathrm{ml}$ penicillin, $0.25 \mu \mathrm{g} / \mathrm{ml}$ fungizone and $3.7 \mathrm{~g}$ sodium bicarbonate at $37^{\circ} \mathrm{C}$ in ambient air with $5 \% \mathrm{CO}_{2}$.

Preparation of BA solution. 10B-Enriched BA $\left(99 \%{ }^{10} \mathrm{~B}\right)$ was used as the boron drug in this study and was purchased from Aldrich Inc. (Darmstadt, Germany). BA powder was dissolved in phosphatebuffered saline (PBS) to yield the requiring ${ }^{10} \mathrm{~B}$ concentration, and then processed with a $0.22 \mu \mathrm{m}$ filter to sterilize the solution. The stock solution of BA $\left(6,000 \mu \mathrm{g}{ }^{10} \mathrm{~B} / \mathrm{ml}\right)$ was stored at $4^{\circ} \mathrm{C}$. (Amounts of boron in the solution or sample were expressed as $\mu \mathrm{B}$.)

Chemical treatment. For treatment, $2 \times 10^{6} \mathrm{HepG} 2$ cells were seeded and cultured in $10 \mathrm{~cm}$ cell culture dishes. Medium with pH 5.4 was prepared by hydrochloric acid titration. For the $\mathrm{pH} 5.4$ treatment group, cells were cultured for $48 \mathrm{~h}$ in $\mathrm{pH} 7.4$ medium, rinsed with $2 \mathrm{ml}$ of $\mathrm{pH} 5.4$ medium and then cultured in $\mathrm{pH} 5.4$ medium during $25 \mu \mathrm{g}{ }^{10} \mathrm{~B} / \mathrm{ml} \mathrm{BA}$ treatment for 5, 30 and $180 \mathrm{~min}$.

For cell membrane fluidity assays, water-soluble cholesterol (Sigma, St. Louis, MO, USA) was used to change the cell membrane composition and to increase lipid rafts in cell membrane as described previously (27). Briefly, cells were cultured in glucosefree DMEM containing $10 \%$ heat-inactivated fetal bovine serum for $47 \mathrm{~h}$, treated with different concentrations of water-soluble cholesterol for $1 \mathrm{~h}$ and then treated with $25 \mu \mathrm{g}{ }^{10} \mathrm{~B} / \mathrm{ml}$ BA for $5 \mathrm{~min}$.

For glucose treatment, cells were cultured in glucose-free DMEM for $24 \mathrm{~h}$. After glucose starvation, the medium was replaced with fresh medium with different glucose concentrations, and cells were then cultured for $48 \mathrm{~h}$. Afterward, cells were treated with $25 \mu \mathrm{g}$ ${ }^{10} \mathrm{~B} / \mathrm{ml} \mathrm{BA}$ for $180 \mathrm{~min}$.

For co-treatment, $3 \mathrm{mM}$ glucose and BA were added together during 180-min incubation. For $4^{\circ} \mathrm{C}$ treatment, cells were cultured for $48 \mathrm{~h}$, the medium was removed and the cells were transferred into an incubator at $4^{\circ} \mathrm{C}$ for $10 \mathrm{~min}$. Afterward, cells were treated with culture medium containing $25 \mu \mathrm{g}{ }^{10} \mathrm{~B} / \mathrm{ml} \mathrm{BA}$ at $4^{\circ} \mathrm{C}$ for $5 \mathrm{~min}$.

Cell harvest. After treatment, cells were washed with $5 \mathrm{ml}$ PBS at $4^{\circ} \mathrm{C}$ three times. The cells were collected in $1 \mathrm{ml}$ PBS after scraping. The resulting cell suspension was transferred into Eppendorf tubes 


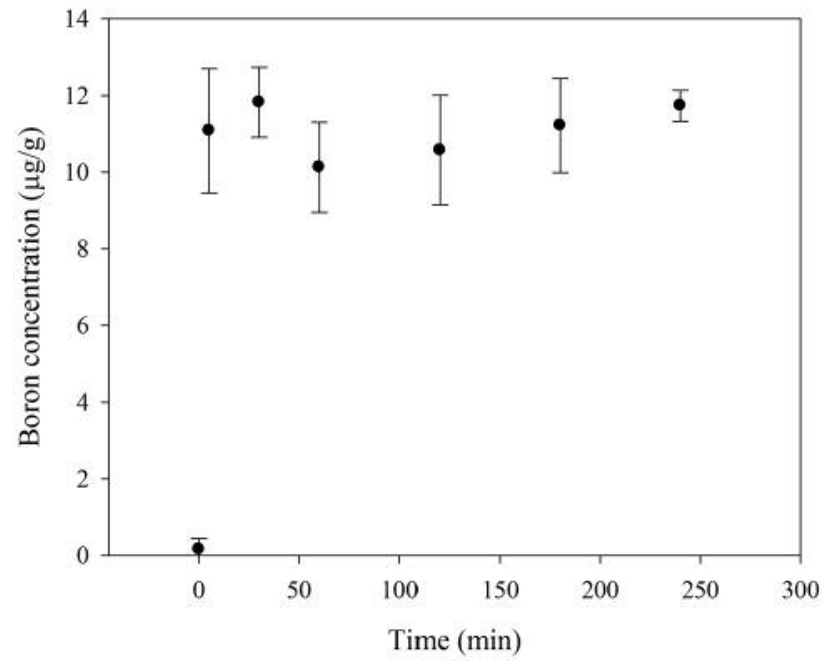

Figure 1. Time course of the boron uptake of HepG2 cells treated with boric acid (BA). HepG2 cells were cultured for $48 \mathrm{~h}$ and then treated with $25 \mu \mathrm{g}{ }^{10} \mathrm{~B} / \mathrm{ml} \mathrm{BA}$ for different times. Data are means $\pm S D(n=3-6)$.

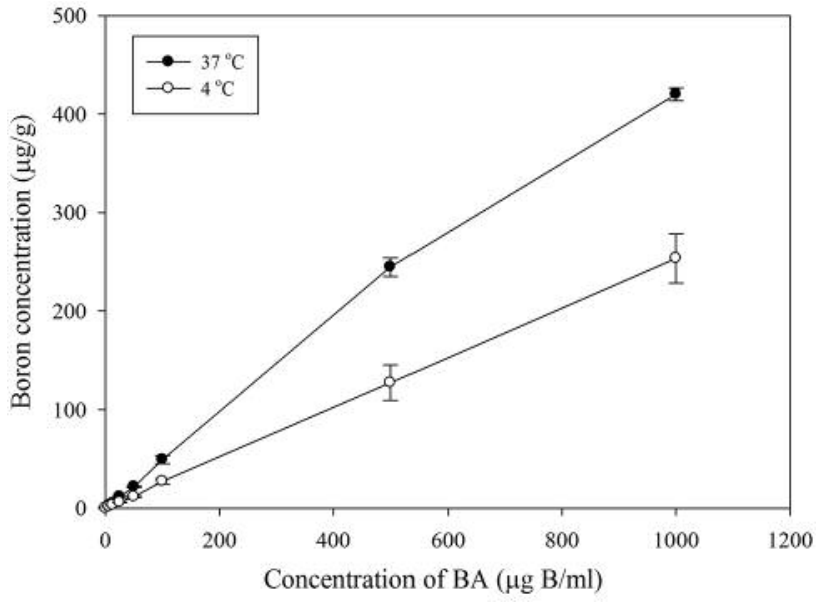

Figure 2. Boron uptake of HepG2 under different boric acid (BA) concentrations and temperature conditions. HepG2 cells were cultured for $48 \mathrm{~h}$ and treated with different concentrations of ${ }^{10} \mathrm{~B} / \mathrm{ml} \mathrm{BA}$ for 5 min at $37^{\circ} \mathrm{C}$ or $4^{\circ} \mathrm{C}$. The slope of the trend line for the $37^{\circ} \mathrm{C}$ group was $0.4346\left(R^{2}=0.994\right)$. The slope of the trend line for the $4^{\circ} \mathrm{C}$ group was $0.254\left(R^{2}=0.9999\right)$. Data are means $\pm S D(n=3)$.

different time points. As shown in Figure 1, the boron concentration in HepG2 cells rapidly increased within the first $5 \mathrm{~min}$ and remained at a stable level from 10 to $12 \mu \mathrm{g} / \mathrm{g}$ for $240 \mathrm{~min}$. These data suggest that BA likely enters the tumor cells via simple diffusion. For further confirmation of the simple diffusion mechanism, we repeated the assay at two different temperatures: $37^{\circ} \mathrm{C}$ and $4^{\circ} \mathrm{C}$. HepG2 cells were treated with 6.25 to $1,000 \mu \mathrm{g} 10 \mathrm{~B} / \mathrm{ml} \mathrm{BA}$ at either $37^{\circ} \mathrm{C}$ or $4^{\circ} \mathrm{C}$ for $5 \mathrm{~min}$ before harvesting.

As shown in Figure 2, we found a linear correlation between the boron concentrations at both temperatures. The slope at $37^{\circ} \mathrm{C}$ and $4^{\circ} \mathrm{C}$ was determined to be $0.43\left(\mathrm{R}^{2}=0.99\right)$ and $0.25\left(R^{2}=1.00\right)$, respectively. The diffusion rate of $\mathrm{BA}$ at $4^{\circ} \mathrm{C}$ appears to be lower than at $37^{\circ} \mathrm{C}$. Based on Fick's law of diffusion, these data further support our belief that simple diffusion is the primary mechanism of BA uptake in HepG2 cells.

Effect of glucose-BA interaction on uptake of BA in HepG2 cells. To examine whether altered glucose level could influence the uptake of BA, after $24 \mathrm{~h}$ glucose starvation, HepG 2 cells were cultured in medium with different glucose levels for $48 \mathrm{~h}$. The cells were then treated with $25 \mu \mathrm{g}$ ${ }^{10} \mathrm{~B} / \mathrm{ml} \mathrm{BA}$ for $3 \mathrm{~h}$ to ensure sufficient uptake. We also included a co-treatment group ( $3 \mathrm{mM}$ glucose plus $25 \mu \mathrm{g}$ ${ }^{10} \mathrm{~B} / \mathrm{ml} \mathrm{BA}$ ) for comparison. As shown in Figure 3, we found no significant difference in boron uptake with glucose pretreatment or co-treatment. These data indicate that glucose level and glucose influx appear not influence the accumulation of BA in HepG2 cells.
Mechanistic analysis of BA transportation in HepG2 cells. To analyze HepG2 cell uptake of BA over time, HepG2 cells were incubated with $25 \mu \mathrm{g}{ }^{10} \mathrm{~B} / \mathrm{ml}$ and $\mathrm{BA}$ was assayed at 


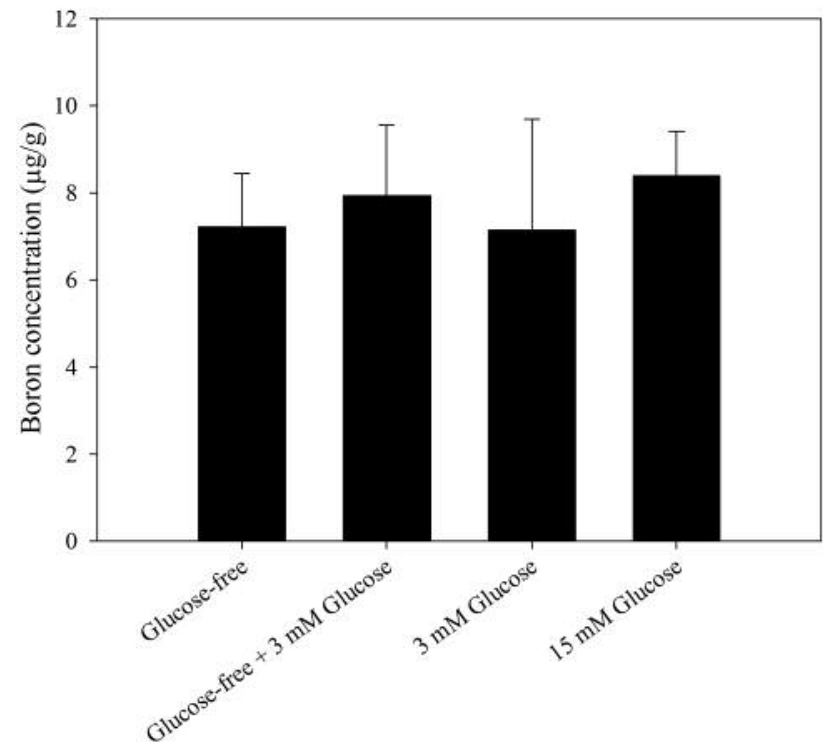

Figure 3. Boron uptake of HepG2 cells under different glucose concentrations. HepG2 cells were glucose starved by culture in glucosefree medium for 24 h. After starvation, cells were treated with glucose-free, $3 \mathrm{mM}$ glucose or $15 \mathrm{mM}$ glucose for $48 \mathrm{~h}$ and then treated with $25 \mu \mathrm{g}$ ${ }^{10} \mathrm{~B} / \mathrm{ml}$ boric acid (BA) for $3 \mathrm{~h}$. For one of the glucose-free groups, $3 \mathrm{mM}$ glucose was added during the BA treatment. Data are means $\pm S D(n=3)$.

Effect of an acidic microenvironment on uptake of BA in HepG2 cells. To explore whether cancer cells could uptake more BA under acidic conditions, HepG2 cells were treated with $25 \mu \mathrm{g}{ }^{10} \mathrm{~B} / \mathrm{ml} \mathrm{BA}$ for 5,30 , and $180 \mathrm{~min}$ in either $\mathrm{pH}$ 7.4 or $\mathrm{pH} 5.4$ medium to mimic the reported acidity levels of the tumor microenvironment. As shown in Figure 4, we found no statistically significant increase in BA uptake within the same $\mathrm{pH}$ group; however, there was a slight increase in boron level at $\mathrm{pH} 5.4$ with a longer incubation time. However, due to large standard error values for the $\mathrm{pH}$ 5.4 group, we concluded that the data only suggest the possibility that an acidic environment might weakly influence the uptake of BA in cancer cells.

Effect of cell membrane fluidity on uptake of BA in HepG2 cells. To further investigate whether cell membrane fluidity can affect BA uptake in cancer cells, HepG2 cells were pretreated with $10,100,300$, or $500 \mu \mathrm{g} / \mathrm{ml}$ water-soluble cholesterol to alter their cell membrane fluidity. The cells were then treated with $25 \mu \mathrm{g}{ }^{10} \mathrm{~B} / \mathrm{ml}$ BA for $5 \mathrm{~min}$ before cell harvesting and boron quantification. As shown in Figure 5, we observed no statistically significant differences in BA uptake. However, the data suggest that cell membrane fluidity might weakly impact the uptake of BA in HepG2 cells.

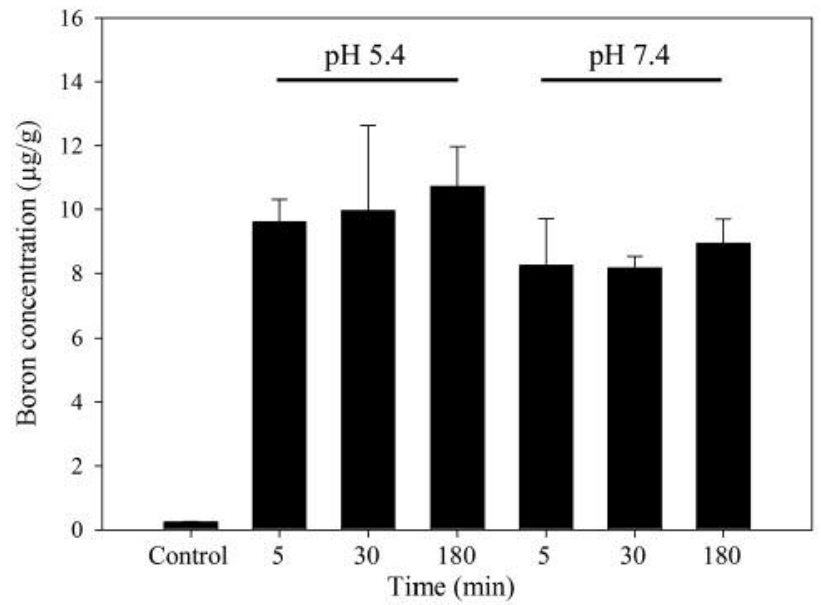

Figure 4. Boron uptake of HepG2 cells under different pH conditions. HepG2 cells were cultured for $48 \mathrm{~h}$ and then treated with $25 \mu \mathrm{g}{ }^{10} \mathrm{~B} / \mathrm{ml}$ boric acid in culture medium which had been titrated to either $\mathrm{pH} 5.4$ or $\mathrm{pH} 7.4$ for 5, 30, or $180 \mathrm{~min}$. Data are means $\pm S D(n=3)$. Uptake did not differ significantly between treatments ( $p$-values of 0.2208, 0.3109 and 0.1019 at 5, 30 and $180 \mathrm{~min}$, respectively).

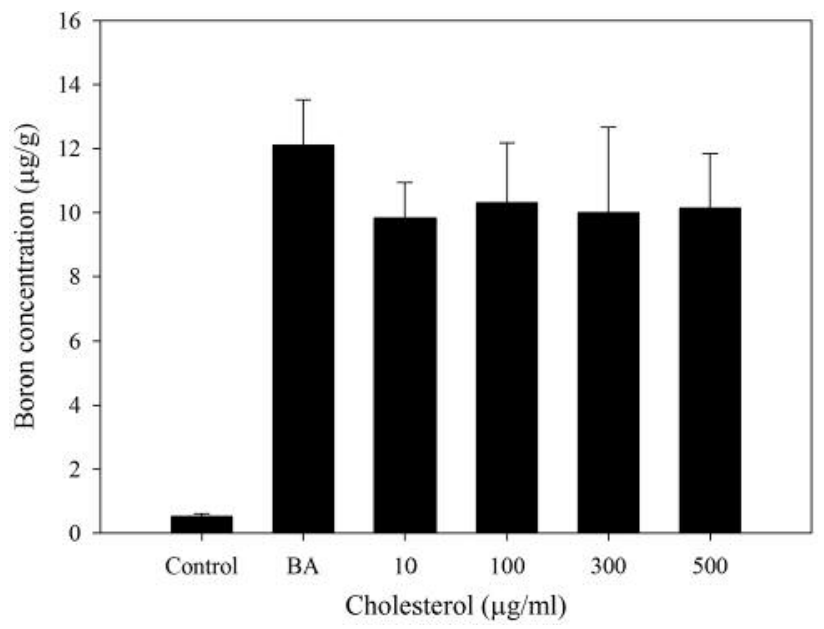

Figure 5. Boron uptake of HepG2 cells cultured with cholesterol. HepG2 cells were cultured for $47 \mathrm{~h}$ and treated with different concentrations of cholesterol for $1 \mathrm{~h}$ and then treated with $25 \mu \mathrm{g}{ }^{10} \mathrm{~B} / \mathrm{ml}$ boric acid for 5 min (n=3). Data are means $\pm S D$. Uptake did not differ significantly between treatments (p-values of 0.0954, 0.2574, 0.2952 and 0.2001 for cells treated with 10,100, 300 and $500 \mu \mathrm{g} / \mathrm{ml}$ cholesterol, respectively).

\section{Discussion}

In this study, we first postulated that glucose influx and glucose level might affect the uptake of BA in HepG2 cells, which could depend on the interaction between BA and 
glucose. However, we found no significant change in BA uptake under different glucose conditions (Figure 3).

The mechanisms of BA transport can be classified into simple diffusion and facilitated transport. Under simple diffusion, BA is directly transported through the cell membrane, with no carrier proteins involved. In this case, the direction of BA transport is determined by the gradient of BA inside and outside of the cell. On the other hand, the facilitated diffusion of BA has been extensively studied in plants. The transportation of BA in plants is assisted by specific carrier proteins, such as nodulin-26-like intrinsic protein NIP5;1, which is a well-known BA channel protein identified in plants (29).

Simple diffusion and facilitated diffusion are both concentration-dependent and bi-directional. In a classic rate of diffusion versus concentration plot, simple diffusion is represented by a linear line (Figure 2), which is the type of diffusion observed in this study. While BA is mainly transported via simple diffusion, we cannot rule-out that the possibility that the diffusion rate might be affected by other factors.

Based on the current understanding of glucose metabolism in $\mathrm{HCC}$, glucose is quickly converted into pyruvate, which is then converted into lactate and acetylCoA to enable high aerobic glycolysis. As a result, the increased lactate level would acidify the tumor microenvironment, while acetyl-CoA acts to regulate fatty acid synthesis $(30,31)$. Based on this information, we investigated whether an acidic microenvironment could affect BA uptake in HepG2 cells. We found that an decrease in $\mathrm{pH}$ value might affect BA uptake by hepatoma cells to a small extent (Figure 4). Therefore, glucose metabolism might still play a role in affecting BA uptake in hepatoma cells due to its contribution to the acidification of the tumor microenvironment.

A microenvironment of lower $\mathrm{pH}$ results in higher cell membrane fluidity (26). This phenomenon occurs when the cancer cell membrane composition is modified by charged lipid head groups (32). The ability of the $\mathrm{pH}$ level to instantly affect cell membrane fluidity and permeability might explain why the uptake of BA would be accelerated at lower pH (Figure 4).

In addition, tumor blood vessels are known to be more acidic ( $\mathrm{pH} 5.0-6.0)$ than the tumor microenvironment $(\mathrm{pH}$ 6.5-6.8) (25), which implies that the cell membrane fluidity of endothelial cells in tumor blood vessels might be higher than that of the surrounding cells. Consequently, this might explain why BA-treated liver tumor sections have a higher alpha-track signal density in tumor blood vessels $(135,748$ tracks $\left./ \mathrm{mm}^{2}\right)$ than in the tumor region $\left(125,096\right.$ tracks $\left./ \mathrm{mm}^{2}\right)$ and in normal liver tissue $\left(45,022\right.$ tracks $\left./ \mathrm{mm}^{2}\right)$ after neutron irradiation, which could lead to the selective destruction of tumor blood vessels as reported (15).
The $\mathrm{pH}$ could also regulate the balance of $\mathrm{BA}$ and borate levels, since the BA form exists at more than $95 \%$ when the $\mathrm{pH}$ value is lower than 7 (33). It should be noted that BA is a water-soluble chemical with a solubility of $4.72,6.23$ and $8.08 \mathrm{wt} \%$ at $20^{\circ} \mathrm{C}, 30^{\circ} \mathrm{C}$ and $40^{\circ} \mathrm{C}$, respectively (34). Boric acid is a Lewis acid and usually exists as borate ions [i.e. $\mathrm{B}(\mathrm{OH}) 4-]$ in water with a $\mathrm{pH}$ value higher than 9 (33).

Considering the complex interactions of BA with other biomolecules via diol bonds, it is interesting to note that trans-diols do not react with $\mathrm{BA}$ at $\mathrm{pH} 5.4$, while $10 \%$ of trans-diols can complex with BA at $\mathrm{pH} 7.4$ (33). On the other hand, the formation of cis-diols decreases by $30 \%$ when the $\mathrm{pH}$ is dropped from 7.4 to 5.4 (33). This phenomenon might suggest that approximately $30 \%$ of BA is released from $\mathrm{BA}-\mathrm{diol}$ complexes when they move into the acidic tumor microenvironment ( $\mathrm{pH}$ 5.0-6.0). However, further experiments are needed to analyze the ratio of free BA to complexed BA in the blood.

In addition to $\mathrm{pH}$ value, the cholesterol level of hepatoma cells is decreased in HCC, especially for cases with advanced hepatomas (24). This altered lipid synthesis results in abnormal lipid composition in cancer cells, including a higher ratio of unsaturated to saturated fatty acids, and a lower ratio of cholesterol to phospholipid, both of which are important determinants of cell membrane fluidity (35). In this study, we found that decreased cell membrane fluidity by cholesterol treatment reduced BA uptake by HepG2 cells (Figure 5), which may partially contribute to the enhanced BA uptake seen in liver tumors compared to the normal liver tissues.

Liver tumors have disorganized, leaky vasculature and lack a lymphatic system. Specifically, tumor-derived vascular endothelial growth factor (VEGF) has been shown to enhance tumor angiogenesis, which not only promotes HCC progression but also increases tumor cell hyperpermeability (36). Since the concentration gradient of BA might affect the passive diffusion rate, it is plausible that BA accumulates in HCC because of the enhanced permeability of tumor blood vessels, which enable BA to enter tumor cells faster than normal neighboring liver tissues. The absence of a lymphatic system in liver tumors might reduce the clearance rate of BA in the tumor, restricting BA in the tumor interstitial fluid and causing selective accumulation of BA in the tumor.

In previous studies, BA has been shown to transiently accumulate in liver tumors in rat and rabbit studies. Our data further reveal that BA is transported into cancer cells by simple diffusion. This new understanding could be used to modify the current treatment protocol to increase efficacy and reduce adverse effects in patients, since BA is not metabolized in animals. Rapid transfusion of saline after BABNCT might accelerate the excretion of BA into urine (37).

In current BPA-BNCT clinical studies, patients with cancer undergo positron-emission tomography with ${ }^{18} \mathrm{~F}$ - 
labeled BPA for prognosis and treatment management (12). However, there is no comparable imaging technique for BA-BNCT. Given the roles of increased liver tumor vasculature and cell permeability in BA uptake and retention, we propose that dynamic contrast-enhanced magnetic resonance imaging (DCE-MRI) could be used as a potential medical imaging method for the prognosis and management of BA-BNCT treatment in HCC. During DCE-MRI measurements, contrast agent wash-in and extravasation changes the $\mathrm{T} 1$ relaxation time of tumor tissues (38). This can enable the computation of the volume transfer constant by associated signal change, which reflects the tumor vascular permeability and perfusion. We believe such properties could correlate positively to BA uptake in HCC. Therefore, DCE-MRI might have the potential to evaluate which patients with HCC are candidates for receiving BA-BNCT.

As our understanding of BA transportation and selective accumulation in tumor tissues improves, we hope that BABNCT will be able to significantly accelerate the development of better and safer HCC therapy.

\section{Acknowledgements}

This work was supported by the National Tsing Hua University preclinical BNCT boron drug development program; Grant No. 106N314CE1.

\section{References}

1 Ferlay J, Soerjomataram I, Ervik M, Dikshit R, Eser S, Mathers C, Rebelo M, Parkin DM, Forman D and Bray F: GLOBOCAN 2012 v1.0, Cancer Incidence and Mortality Worldwide: IARC CancerBase No. 11 [Internet]. International Agency for Research on Cancer 2013. http://globocan.iarc.fr/Pages/fact_sheets_ cancer.aspx

2 Bruix $\mathrm{J}$ and Sherman M: Management of hepatocellular carcinoma: an update. Hepatology 53: 1020-1022, 2011.

3 Sarin SK, Kumar M, Lau GK, Abbas Z, Chan HL, Chen CJ, Chen DS, Chen HL, Chen PJ, Chien RN, Dokmeci AK, Gane E, Hou JL, Jafri W, Jia J, Kim JH, Lai CL, Lee HC, Lim SG, Liu CJ, Locarnini S, Al Mahtab M, Mohamed R, Omata M, Park J, Piratvisuth T, Sharma BC, Sollano J, Wang FS, Wei L, Yuen MF, Zheng SS and Kao JH: Asian-Pacific clinical practice guidelines on the management of hepatitis B: a 2015 update. Hepatol Int 10: 1-98, 2016.

4 Lin S, Hoffmann K and Schemmer P: Treatment of hepatocellular carcinoma: a systematic review. Liver Cancer 1: 144-158, 2012.

5 Tabrizian P, Roayaie S and Schwartz ME: Current management of hepatocellular carcinoma. World J Gastroenterol 20: 1022310237, 2014.

6 Llovet JM, Ricci S, Mazzaferro V, Hilgard P, Gane E, Blanc JF, de Oliveira AC, Santoro A, Raoul JL, Forner A, Schwartz M, Porta C, Zeuzem S, Bolondi L, Greten TF, Galle PR, Seitz JF, Borbath I, Haussinger D, Giannaris T, Shan M, Moscovici M, Voliotis D and Bruix J: Sorafenib in advanced hepatocellular carcinoma. N Engl J Med 359: 378-390, 2008.
7 Colagrande S, Regini F, Taliani GG, Nardi C and Inghilesi AL: Advanced hepatocellular carcinoma and sorafenib: Diagnosis, indications, clinical and radiological follow-up. World J Hepatol 7: 1041-1053, 2015.

8 Barth RF, Vicente MG, Harling OK, Kiger WS, 3rd, Riley KJ, Binns PJ, Wagner FM, Suzuki M, Aihara T, Kato I and Kawabata S: Current status of boron neutron capture therapy of high-grade gliomas and recurrent head and neck cancer. Radiat Oncol 7: 146, 2012.

9 Yong Z, Song Z, Zhou Y, Liu T, Zhang Z, Zhao Y, Chen Y, Jin C, Chen X, Lu J, Han R, Li P, Sun X, Wang G, Shi G and Zhu S: Boron neutron capture therapy for malignant melanoma: first clinical case report in China. Chin J Cancer Res 28: 634-640, 2016.

10 Miyatake S, Kawabata S, Hiramatsu R, Kuroiwa T, Suzuki M, Kondo $\mathrm{N}$ and Ono K: Boron Neutron Capture Therapy for Malignant Brain Tumors. Neurol Med Chir (Tokyo) 56: 361-371, 2016.

11 Suzuki M, Masunaga S, Kinashi Y, Nagata K, Sakurai Y, Nakamatsu K, Nishimura Y, Maruhashi A and Ono K: Intraarterial administration of sodium borocaptate (BSH)/lipiodol emulsion delivers B-10 to liver tumors highly selectively for boron neutron capture therapy: experimental studies in the rat liver model. Int J Radiat Oncol Biol Phys 59: 260-266, 2004.

12 Wang HE, Liao AH, Deng WP, Chang PF, Chen JC, Chen FD, Liu RS, Lee JS and Hwang JJ: Evaluation of 4-borono-2- ${ }^{18} \mathrm{~F}-$ fluoro-L-phenylalanine-fructose as a probe for boron neutron capture therapy in a glioma-bearing rat model. J Nucl Med 45: 302-308, 2004.

13 Chou FI, Chung HP, Liu HM, Chi CW and Lui WY: Suitability of boron carriers for BNCT: accumulation of boron in malignant and normal liver cells after treatment with BPA, BSH and BA. Appl Radiat Isot 67: S105-108, 2009.

14 Lin SY, Lin CJ, Liao JW, Peir JJ, Chen WL, Chi CW, Lin YC, Liu YM and Chou FI: Therapeutic efficacy for hepatocellular carcinoma by boric acid-mediated boron neutron capture therapy in a rat model. Anticancer Res 33: 4799-4809, 2013.

15 Yang CH, Lin YT, Hung YH, Liao JW, Peir JJ, Liu HM, Lin YL, Liu YM, Chen YW, Chuang KS and Chou FI: Autoradiographic and histopathological studies of boric acid-mediated BNCT in hepatic VX2 tumor-bearing rabbits: Specific boron retention and damage in tumor and tumor vessels. Appl Radiat Isot 106: 176-180, 2015.

16 Murray FJ: A comparative review of the pharmacokinetics of boric acid in rodents and humans. Biol Trace Elem Res 66: 331341, 1998.

17 Dordas C and Brown PH: Permeability and the mechanism of transport of boric acid across the plasma membrane of Xenopus laevis oocytes. Biol Trace Elem Res 81: 127-139, 2001.

18 Damaghi M, Wojtkowiak JW and Gillies RJ: pH sensing and regulation in cancer. Front Physiol 4: 370, 2013.

19 Annibaldi A and Widmann C: Glucose metabolism in cancer cells. Curr Opin Clin Nutr Metab Care 13: 466-470, 2010.

20 Moreno-Sánchez R, Rodríguez-Enríquez S, Marín-Hernández A and Saavedra E: Energy metabolism in tumor cells. FEBS J 274: 1393-1418, 2007.

21 Pappin B, Kiefel MJ and Houston TA: Boron-carbohydrate interactions. In: Carbohydrates - Comprehensive Studies on Glycobiology and Glycotechnology. Chang Chuan-Fa (Ed.). Croatia, InTech, pp. 37-54, 2012. https://www.intechopen.com/ books/carbohydrates-comprehensive-studies-on-glycobiologyand-glycotechnology/boron-carbohydrate-interactions 
22 Dordas $\mathrm{C}$ and Brown PH: Permeability of boric acid across lipid bilayers and factors affecting it. J Membr Biol 175: 95-105, 2000.

23 Beloribi-Djefaflia S, Vasseur S and Guillaumond F: Lipid metabolic reprogramming in cancer cells. Oncogenesis 5: e189, 2016.

24 Jiang J-t, Xu N, Zhang X-y and Wu C-p: Lipids changes in liver cancer. J Zhejiang Univ Sci B 8: 398-409, 2007.

$25 \mathrm{Du}$ J, Lane LA and Nie S: Stimuli-responsive nanoparticles for targeting the tumor microenvironment. J Control Release 219: 205-214, 2015.

26 Yamaguchi T, Koga M, Fujita Y and Kimoto E: Effects of pH on membrane fluidity of human erythrocytes. J Biochem 91: 1299-1304, 1982.

27 Li YC, Park MJ, Ye SK, Kim CW and Kim YN: Elevated levels of cholesterol-rich lipid rafts in cancer cells are correlated with apoptosis sensitivity induced by cholesterol-depleting agents Am J Pathol 168: 1107-1118, 2006.

28 Hsu CF, Lin SY, Peir JJ, Liao JW, Lin YC and Chou FI: Potential of using boric acid as a boron drug for boron neutron capture therapy for osteosarcoma. Appl Radiat Isot 69: 17821785, 2011.

29 Wang S, Yoshinari A, Shimada T, Hara-Nishimura I, MitaniUeno N, Feng Ma J, Naito S and Takano J: Polar localization of the NIP5; 1 boric acid channel is maintained by endocytosis and facilitates boron transport in Arabidopsis roots. Plant Cell 29: 824-842, 2017.

30 Jóźwiak P, Forma E, Bryś M and Krześlak A: $O$-GlcNAcylation and metabolic reprograming in cancer. Front Endocrinol (Lausanne) 5: 145, 2014.

31 Kato Y, Ozawa S, Miyamoto C, Maehata Y, Suzuki A, Maeda T and Baba Y: Acidic extracellular microenvironment and cancer. Cancer Cell Int 13: 89, 2013.
32 Leung C-Y, Palmer LC, Kewalramani S, Qiao B, Stupp SI, Olvera de la Cruz M and Bedzyk MJ: Crystalline polymorphism induced by charge regulation in ionic membranes. Proc Natl Acad Sci USA 110: 16309-16314, 2013.

33 Bishop M, Shahid N, Yang J and Barron AR: Determination of the mode and efficacy of the cross-linking of guar by borate using MAS ${ }^{11} \mathrm{~B}$ NMR of borate cross-linked guar in combination with solution ${ }^{11} \mathrm{~B}$ NMR of model systems. Dalton Trans 17: 2621-2634, 2004.

34 Briggs M: Boron Oxides, Boric Acid and Borates. In: KirkOthmer Encyclopedia of Chemical Technology. Seidel A (ed.). New York, John Wiley \& Sons Inc., pp. 241-294, 2001.

35 Lande MB, Donovan JM and Zeidel ML: The relationship between membrane fluidity and permeabilities to water, solutes, ammonia and protons. J Gen Physiol 106: 67-84, 1995.

36 Zhu AX, Duda DG, Sahani DV and Jain RK: HCC and angiogenesis: possible targets and future directions. Nat Rev Clin Oncol 8: 292-301, 2011.

37 Wong LC, Heimbach MD, Truscott DR and Duncan BD: Boric acid poisoning: report of 11 cases. Can Med Assoc J 90: 10181023,1964

38 Gaddikeri S, Gaddikeri RS, Tailor T and Anzai Y: Dynamic contrast-enhanced $\mathrm{mr}$ imaging in head and neck cancer: techniques and clinical applications. Am J Neuroradiol 37: 588-595, 2016.
Received August 16, 2017

Revised September 8, 2017

Accepted September 14, 2017 